\title{
Pre-Law Advising and the Political Science Major: Evidence from Pre-Law Advisors
}

\author{
H. Gibbs Knotts, College of Charleston \\ Claire B. Wofford, College of Charleston
}

ABSTRACT Political science is one of the most popular majors for law school applicants, and studies show that political science majors have high rates of law school admission. In addition, many political science departments have a pre-law advisor. However, little is known about the status of pre-law advising on college campuses or the views of pre-law advisors on political science. This article presents the results of a February 2015 survey of 313 college pre-law advisors from across the United States. The authors discovered that the majority of pre-law advisors hold faculty appointments and serve as pre-law advisors without additional compensation or course releases. Pre-law advisors also rate political science as the second-best major, among 14 popular majors, for preparing students for both admission to and academic success in law school. These findings should be of interest to political scientists as well as other faculty and administrators who are concerned with pre-law advising.

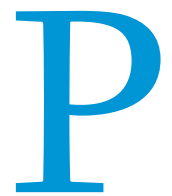
re-law advising and the discipline of political science share a long history. As early as 1968, the APSA offered advice to pre-law advisors in PS: Political Science \& Politics, its journal of record. The APSA Annual Meeting regularly includes short courses devoted to pre-law advising, and job openings in political science-particularly in the American politics and public law subfields-often include pre-law advising as a requirement for the position. Despite this long-standing association, little is known about the relationship between pre-law advising and the discipline of political science.

Although the American Bar Association (ABA) "does not recommend any undergraduate majors or group of courses to prepare for a legal education" (American Bar Association 2015), political science often is seen as an appropriate course of study for those interested in law school. Astin (1984) found that the political science major was frequently selected by freshmen who indicated that they planned to be an attorney and earn a law degree. Among those students, political science was the most popular major (31.7\%), followed by pre-law (15.5\%), business administration (7.8\%),

H. Gibbs Knotts is professor and department chair of political science at the College of Charleston. He can be reached at knottshg@cofc.edu.

Claire B. Wofford is assistant professor of political science at the College of Charleston. She can be reached at woffordcb@cofc.edu. history (5.3\%), and accounting (4.5\%). According to recent data from the Law School Admission Council (LSAC), 18\% of law school applicants were political science majors; the next three most popular majors (i.e., psychology, English, and history) were much less popular, each with rates of approximately $5 \%$ (Law School Admission Council 2015). However, it is not known if these same majors are those recommended by pre-law advisors and we do not have a sense of what pre-law advisors think about the political science major as a pre-law course of study.

As one might expect, there has been normative work about the best majors for law school. For example, Kelley $(1960,1184)-$ who cautioned against the traditional paths of political science or business when preparing for law school-wrote that:

Although general knowledge of the structure of state and national governments and the subtleties of double-entry booking are undoubtedly important to every lawyer and crucial to some, the prospective law student should devote a generous portion of his time to the study of cultural heritage; he should attempt at least a nodding acquaintance with modern science; he should become actually aware of the distinctions between statements of fact and value; he should know when the line has been crossed between the discussion of an idea and the propagation of an ideology.

We found one empirical study in which practicing attorneys and judges rated the top five majors for law school. According to this 
research, they ranked business, political science, economics, English, and philosophy as the best preparation (Martellaro 1984).

In addition, LSAC data reveal that students who major in political science are successful at gaining admission to law school. Although they tend to have LSAT scores that are somewhat lower than those who pursue other majors, the admission rate for political science majors is fairly high, exceeding $80 \%$ in recent years (Law School Admission Council 2015). Given its popularity as a major and the extent to which it may enhance students' chances for admission to law school, examining the nature of pre-law advising and the views of pre-law advisors on political science is an important addition to our understanding of the discipline and how political science can better serve pre-law students and their institutions.
2014 LSAC Directory. The directory included two categories of pre-law advisors: "sole/coordinating" advisors and "supporting" advisors. Because we wanted to focus on the primary advisor at each institution, we sent our survey to sole/coordinating advisors only. Our final mailing list included 1,396 valid e-mail addresses. In addition, each person on the list had one of six regional affiliations with the Pre-Law Advisors National Council: 20\% from the Midwest Association, 31\% from the Northeast Association, 10\% from the Pacific Coast Association, 21\% from the Southern Association, 12\% from the Southwest Association, and 6\% from the Western Association. We received $313 \mathrm{com}-$ pletions, for an overall response rate of $22 \%$. Fortunately, the regional affiliations of our respondents matched well with our population: $19 \%$ from the Midwest region, $28 \%$ from the Northeast region, $11 \%$ from the Pacific Coast region, $20 \%$ from

\section{One of the first questions the survey asked was whether advisors were classified as faculty or staff at their college or university. We discovered that $76 \%$ of respondents identified as faculty and $24 \%$ identified as staff.}

In addition to discussions about different courses of study pursued by those interested in law school, the literature raises questions about the use of faculty or staff resources for pre-law advising. Political scientist Rebecca Gill investigated 16 peer institutions and found that 11 schools had professional staff and five employed faculty or instructors as pre-law advisors (Haynie 2014); however, it is not known whether this finding would hold up nationally.

Likewise, nothing is known about the educational background of pre-law advisors. Does the typical pre-law advisor have a PhD, a JD, both, or neither? In an effort to learn about the qualifications and preparation of these advisors, our survey included questions about their educational background.

Given the substantial changes taking place in legal education in the United States, we believe that this is a particularly appropriate time to investigate pre-law advising. Law school enrollment numbers continue to decline and the cost of attendance remains high (Olson and Segal 2014). The price tag for a legal education is particularly problematic, given the challenges of gaining employment after graduation (Tamanaha 2012). Some law schools, confronted with smaller applicant pools, have even begun to admit more and potentially less qualified students (Rivard 2015).

This article offers an initial look at these issues by presenting the results of a survey of pre-law advisors at US colleges and universities. Our questions addressed a range of topics, focusing particularly on the presence and extent of pre-law curricula and the perspectives of pre-law advisors on political science as preparation for admission to and success in law school. We also compared the opinions of pre-law advisors about political science with other popular undergraduate majors. It is our hope that political science departments, pre-law programs, and university administrators can use these findings to assess their own programs and to develop strategies for improvement.

\section{DATA AND METHODS}

We conducted a web-based survey of pre-law advisors in February 2015. We sent surveys to all pre-law advisors listed in the Fall the Southern region, $13 \%$ from the Southwest region, and $9 \%$ from the Western region. We sent an initial e-mail on February 4, 2015, and two reminder e-mails requesting completion of the survey, which included 26 questions.

\section{FINDINGS}

One of the first questions the survey asked was whether advisors were classified as faculty or staff at their college or university. We discovered that $76 \%$ of respondents identified as faculty and $\mathbf{2 4} \%$ identified as staff. As one might expect, these percentages differed considerably across the type of institution. Using three Carnegie classifications (i.e., bachelors, masters, and doctoral), we found that $73 \%$ of advisors from bachelors institutions, $92 \%$ from masters institutions, and only $55 \%$ from doctoral institutions were faculty. Our findings are similar to previous research, reporting that $69 \%$ of schools utilized staff and $31 \%$ relied on faculty (Haynie 2014). We also note that pre-law advisors held a variety of faculty titles, including adjunct professor, lecturer, assistant professor, associate professor, professor, department chair, associate dean, and even dean. Staff titles included academic advisor, coordinator, and director. Our survey also was completed by a university librarian and a university general counsel.

We asked pre-law advisors how long they had worked in their current position. As one might expect, there was considerable range in the amount of experience, from only a few months to one respondent who reported serving as a pre-law advisor for 50 years. Overall, we discovered that pre-law advisors have considerable experience, serving an average of 12.4 years in the position. We also found that there was a statistically significant difference (i.e., $\mathrm{p}<0.05$ ) between the years of experience for faculty and staff. Faculty served in the position for an average of 13.2 years, whereas staff served for an average of 9.6 years. There were no notable differences in the amount of time that a pre-law advisor had served across institutional type.

We also wanted to study the educational background of pre-law advisors. Given the high percentage of faculty serving as pre-law advisors, it is not surprising that $58 \%$ of respondents 
hold a PhD. As mentioned previously, bachelors and masters institutions were more likely to have faculty serving as pre-law advisors than doctoral institutions. Therefore, it was not particularly surprising that there was a higher percentage of pre-law advisors with a $\mathrm{PhD}$ at bachelorsand masters-level schools than at doctoral-granting institutions. We also asked how many pre-law advisors had law degrees and discovered that $43 \%$ had a JD. Doctoral institutions had a slightly higher percentage of JD pre-law advisors than masters and bachelors institutions. In addition, we found that $19 \%$ of pre-law advisors indicated that they had both a PhD and a JD. Last, we found that $18 \%$ of respondents indicated that they had neither a PhD nor a JD.

We discovered that almost all pre-law advisors work without monetary compensation. According to the survey results, $93 \%$ of the respondents indicated that they did not receive any additional compensation for serving as a pre-law advisor. Of those who reported additional compensation, the amount ranged from $\$ 100$ to $\$ 25,000$, with an average of approximately $\$ 5,400$. Stipend amounts were substantially higher at masters and doctoral institutions than they were at bachelors institutions.

The results were similar regarding course-release time. We asked respondents who were also faculty whether they received any course releases for serving as pre-law advisor, and we were surprised to learn that $81 \%$ of respondents did not. Only $13 \%$ reported receiving a one-course release and only $5 \%$ reported being released from two or more courses in the academic year. Several respondents commented on the lack of course releases as a particularly challenging aspect of their job. As one might expect, the amount of course-release time was greater for prelaw advisors at doctoral-granting institutions than at masters and bachelors schools.

Our survey also included several questions about additional resources available to pre-law advisors. We found that only $19 \%$ of respondents had a separate budget for pre-law advising. Among those who indicated a separate budget, the amount ranged from $\$ 100$ to $\$ 75,000$, with an average of approximately $\$ 7,300$. We were surprised to find that $29 \%$ of pre-law advisors at bachelorsonly schools had a separate budget, compared to $13 \%$ at masters schools and $25 \%$ at doctoral-granting institutions.

We also asked about the availability of Law School Admission Test (LSAT) preparation courses on the respondents' campuses. We found that $31 \%$ of advisors indicated that their school offered LSAT preparation and $69 \%$ indicated that their school did not. Several respondents mentioned that they provided informal assistance with the LSAT as part of their advising duties, such as sponsoring LSAT workshops and offering mock LSAT testing.
Last, the likelihood of LSAT preparation did not differ significantly by institutional type.

Given the national news about the decline of law school applications and the difficult job market facing law school graduates, we were interested in how pre-law advisors would rate the job prospects for today's graduates. The results from this question, shown in figure 1, indicate that slightly more than $50 \%$ of prelaw advisors rated job prospects for law school graduates as either "Poor" or "Fair." In fact, the modal rating category was "Fair," at $42 \%$. The other half of respondents were slightly more positive about job prospects for today's law school graduates: $37 \%$ rated them as "Good" and 10\% as "Very Good." Only 3\% of respondents rated job prospects as "Excellent."

We also investigated the presence of specific pre-law programs at colleges and universities. We asked pre-law advisors whether there was a pre-law major, a pre-law minor, or a pre-law concentration at their institution. As shown in figure 2, a pre-law concentration was the most common type of program, with $33 \%$ of respondents indicating its presence. A pre-law minor was also a fairly common occurrence, with $28 \%$ of pre-law advisors reporting a concentration. Pre-law majors, however, were rare, with only $6 \%$ of respondents indicating that it was possible to major in pre-law at their institution. It is interesting that whereas one respondent expressed a strong desire to have "a more formal pre-law curricular option," that same respondent also stated that "students can do a great job in law school and as lawyers without the curricular offering." Another respondent commented that the ABA and the LSAC both recommend against students pursuing a pre-law major, advice that-given the dearth of pre-law majors-institutions seem to be following. There were not many differences in the number of pre-law majors, minors, and concentrations among institutional types. We discovered that a slightly higher percentage 
of masters institutions had a pre-law concentration (i.e., 41\%), compared to only $30 \%$ at both doctoral-granting and bachelors institutions.

We then asked pre-law advisors for feedback on 14 common majors for students planning to attend law school. We asked them to rate each major in terms of how well it prepares students for admission to and academic success in law school. We decided to include these two questions in our survey because we believed that gaining admission to law school and being a successful law student do not necessarily require the same skills or attributes. We asked pre-law advisors to rate majors in general rather than a particular
International studies, an interdisciplinary major that political science department chairs rate as less academically rigorous than political science (Knotts and Schiff 2015), appeared in the middle. We were surprised to find that sociology and psychology, two other traditional liberal-arts majors popular among pre-law students, did not receive higher ratings from pre-law advisors. It also was interesting to note that the three majors with close connections to the study of law (i.e., legal studies, pre-law, and criminal justice) were rated less well by pre-law advisors, with criminal justice ranking in last place. Whether right or wrong, criminal justice programs are known

\section{There appears to be little difference in pre-law advisors' sense of the best undergraduate majors for admission to versus performance in law school.}

program at their institution. We instructed respondents to leave the question blank if they were not able to provide a rating.

Figure 3 shows the ratings of majors in terms of how well they were rated as preparation for admission to law school. The solid bars represent the percentage of respondents who rated the major as "Very Good" or "Excellent." As shown in figure 3, pre-law advisors rated political science as the second-best major in terms of preparation for law school, slightly behind philosophy. The traditional liberal-arts majors of history, English, and economics were also rated fairly highly, ranking third, fourth, and fifth, respectively. In the open-ended section of the survey, respondents also specifically mentioned "hard sciences like engineering" and even physics as helpful majors. more for providing job training for law-enforcement personnel than for preparation for law school.

Figure 4 presents results from the survey question about how well particular majors prepare students for academic success while in law school. The results illustrated in figure 4 are similar to those in figure 3. Philosophy and political science are again rated the highest by pre-law advisors, whereas communication and criminal justice are again rated the lowest. The only notable difference between the results presented in figures 3 and 4 was that English and history reversed places in the ranking. There appears to be little difference in pre-law advisors' sense of the best undergraduate majors for admission to versus performance in law school.

\section{Figure 2}

The Presence of Pre-Law Majors, Minors, and Concentrations on Campuses

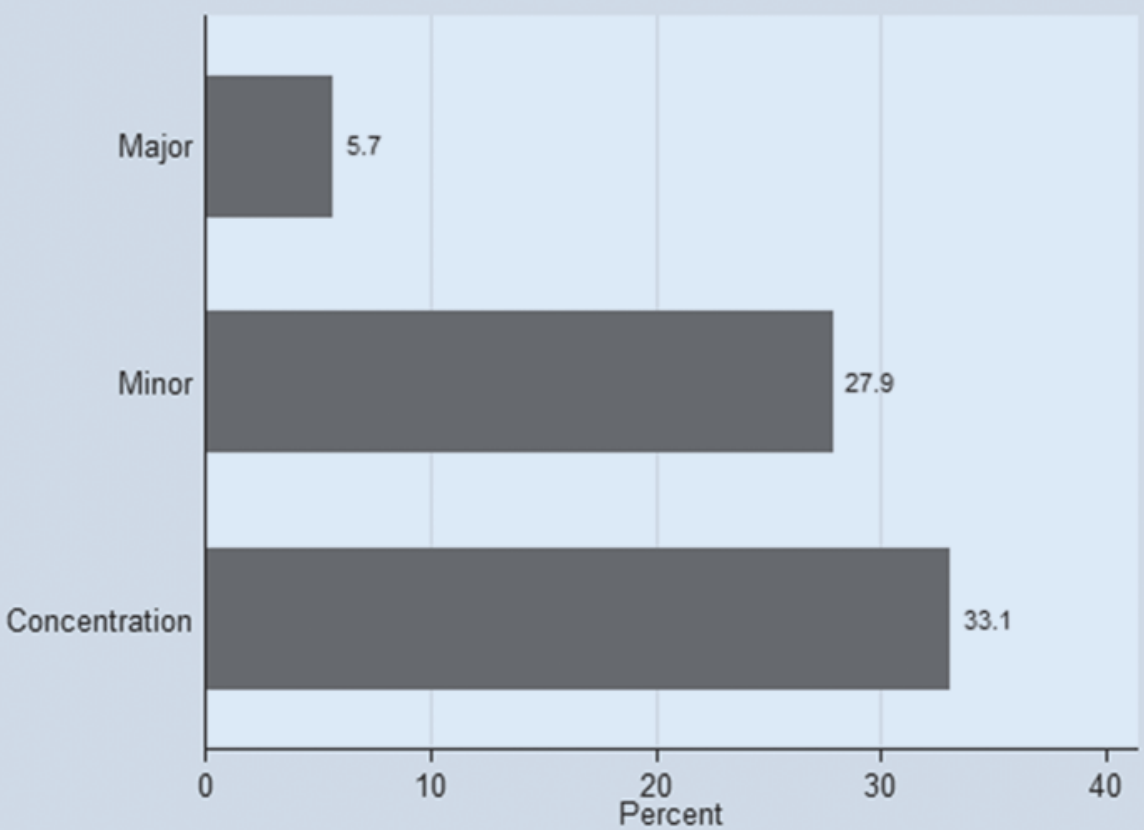

We began by investigating the differences between the ways that JD and non-JD advisors rated political science. We found that $81 \%$ with a JD rated political science as "Very Good" or "Excellent" preparation for admission to law school, compared to $87 \%$ of those without a JD. Likewise, $79 \%$ of advisors with a JD rated political science as "Very Good" or "Excellent" preparation for academic success while in law school, compared to $87 \%$ of non-JD advisors.

We also explored differences in the ways that faculty versus staff rated political science. We found that $85 \%$ of faculty rated political science as "Very Good" or "Excellent" preparation for admission to law school, compared to $81 \%$ of staff. In terms of rating political science as preparation for academic success in law school, $85 \%$ of faculty rated the major as "Very Good" or "Excellent," compared to $78 \%$ of staff. 
Figure 3

\section{Pre-Law Advisors' Ratings of How Well a Major Prepares Students} for Admission to Law School

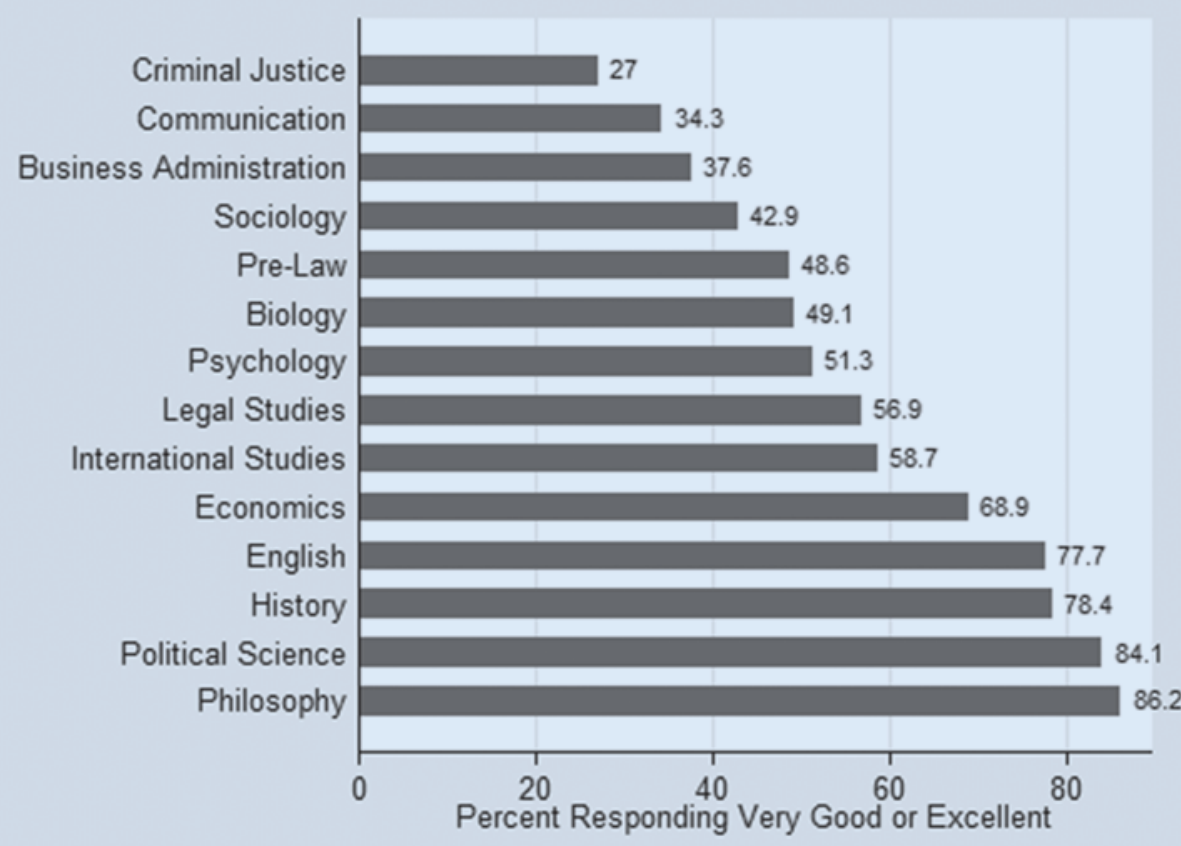

Figure 4

Pre-Law Advisors' Ratings of How Well a Major Prepares Students for Academic Success in Law School

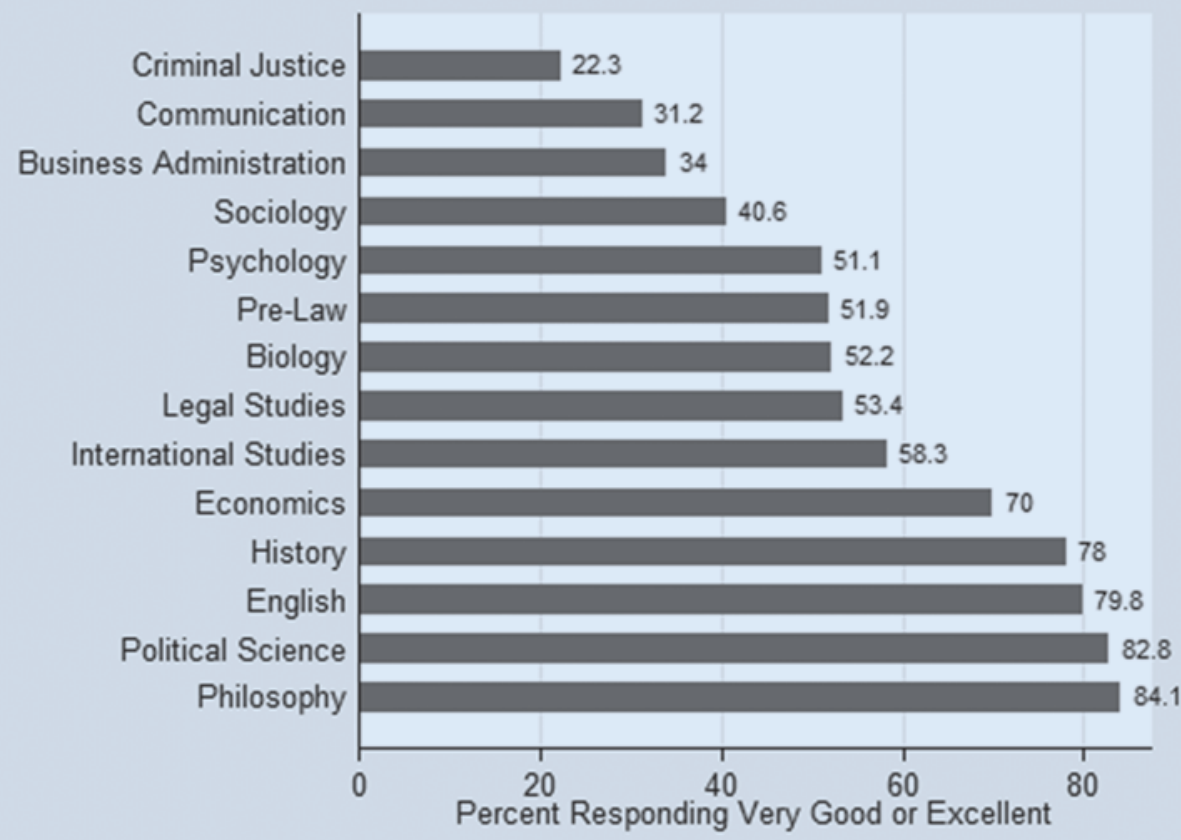

variables, we used an ordinal logit model. We included six independent variables: whether the pre-law advisor was faculty or staff, the number of years the pre-law advisor has served in the position, whether the pre-law advisor has a JD, whether the advisor was a political scientist, the Carnegie classification for the advisor's school, and the average SAT score at the respondent's institution. Last, to more easily interpret our results, we report some predicted probabilities for the significant independent variables.

The results of our model are in table 1. As shown in the table, whether pre-law advisors selfclassified as faculty or staff was not a significant predictor of how they rated the political science major. The average SAT score at advisors' institutions also does not affect their ratings of political science. These two results were consistent across both of our dependent variables. The results for the Carnegie variable (i.e., bachelors $=1$, masters $=2$, and doctoral $=3$ ) indicate that advisors at higher Carnegie-classification schools rated the major less favorably than those at lower Carnegie-classification schoolsbut only for admission to law school. There was no difference among the advisors at different types of institutions about how well political science prepares students for academic success in law school.

Regarding advisors' own backgrounds, those who were political scientists were more likely to rate political science more positively, across both dependent variables. Having a JD did not affect a prelaw advisor's rating of political science in terms of admission to law school, but it affected the second dependent variable. A prelaw advisor with a JD was significantly more likely to rate political science less positively for success in law school. ${ }^{2}$

In addition, years on the job

Next, we used a regression model to predict the rating of the political science major in terms of preparation for admission to and performance in law school. Given the categorical dependent had a positive and significant effect on the rating of the political science major-again across both dependent variables. A pre-law advisor with more years in the position was more likely to rate 
political science more positively, in terms of both admission to and success in law school, even after controlling for the advisor's own background in political science. 3

In terms of substantive effects, the predicted probabilities show that having more experience as a pre-law advisor has a significant effect on the evaluation of the political science major. As the variable capturing the number of years serving as pre-law advisor increases from its minimum to its maximum, the probability of rating political science as an "Excellent" major for admission to law school increases from $32 \%$ to $61 \%$ an increase of 29 percentage points. As for whether the major as "Excellent" preparation for performance in law school than those who are not political scientists. Political scientists are more favorable toward their own discipline, but the effect is not overwhelming. The time spent as an advisor appears to have a greater effect.

\section{DISCUSSION AND CONCLUSION}

Given the strong connection between political science and law school and the dearth of knowledge about what pre-law advisors think about the discipline, our study provides new information that political scientists should find helpful as they guide students

\section{However, we discovered differences among different categories of pre-law advisors. Those with a JD rate political science less favorably than non-JDs-at least in terms of helping students perform well in law school. As mentioned by several respondents, this may reflect their sense that skills are more important than content for academic success in law school-skills that other majors also may provide.}

is "Excellent" preparation for performance in law school, the increase is even larger, at approximately 37 percentage points. ${ }^{4}$ It appears, therefore, that those who have been a pre-law advisor longer are more inclined to view political science as more helpful for admission to law school than those with less experience. They also are much more likely than those with less experience to view it as helpful for academic success in law school.

The type of institution has a moderate substantive effect. Advisors who work at doctoral-granting institutions are $14 \%$ less likely to rate political science as "Excellent" preparation for admission to law school than those who work at bachelors institutions and $7 \%$ less likely to do so than those who work at masters institutions. 5

If a pre-law advisor is also a political scientist, this increases the ratings of political science-but perhaps not by as much as one might expect. If advisors are political scientists, they are $15 \%$ more likely to rate the discipline as "Excellent" preparation for admission to law school and $14 \%$ more likely to rate it

Table 1

Rating the Political Science Major for Admission to and Success in Law School

\begin{tabular}{lcc} 
& $\begin{array}{c}\text { Admission to } \\
\text { Law School }\end{array}$ & $\begin{array}{c}\text { Academic Success } \\
\text { in Law School }\end{array}$ \\
\hline Faculty & $0.550(0.364)$ & $0.204(0.377)$ \\
\hline Years Served & $0.024^{*}(0.013)$ & $0.034^{* *}(0.014)$ \\
\hline JD & $-0.346(0.272)$ & $-0.587^{* *}(0.290)$ \\
\hline Political Scientist & $0.721^{* * *}(0.281)$ & $0.637^{* * *}(0.299)$ \\
\hline Carnegie & $-0.307^{*}(0.183)$ & $-0.100(0.195)$ \\
\hline SAT & $0.002(0.001)$ & $0.000(0.000)$ \\
\hline N & 227 & 206
\end{tabular}

Note: Entries are ordinal logit regression coefficients with standard errors in parentheses. ${ }^{*} p<0.10 ;{ }^{* *} p<0.05$; ${ }^{* * *} p<0.01$ (two-tailed test). interested in pursuing a legal education. In addition, our results provide political scientists an opportunity to see how their approach compares with other schools and to consider how the discipline as a whole might better prepare students for law school.

Our findings indicate that the majority of pre-law advisors are faculty members, that they operate without a separate budget, and that few receive course releases or additional compensation for their pre-law advisory duties. We also found that pre-law advisors are favorable toward a major in political science regarding both admission to and academic success in law school. Indeed, only a philosophy major was evaluated more highly.

However, we discovered differences among different categories of pre-law advisors. Those with a JD rate political science less favorably than non-JDs-at least in terms of helping students perform well in law school. As mentioned by several respondents, this may reflect their sense that skills are more important than content for academic success in law school-skills that other majors also may provide.

It is not surprising that advisors who were political scientists were more likely to evaluate political science positively. Nevertheless, marked differences were observed between longer- and shorter-serving pre-law advisors. Longer-serving advisors feel particularly positive about a political science major; indeed, as pre-law advising experience increases, the probability of deeming political science as "Excellent" as preparation for both admission to and academic success in law school increases substantially. Presuming that more experience as a pre-law advisor generates a better understanding of law school admissions and the rigors of law school, political scientists should know that their discipline remains a well-regarded major for those interested in a legal education.

We hope that future research will look beyond specific majors and focus on the ways that certain classes prepare students for law school. As Grigsby and Murphy (2012) discovered, admission to law school may be more closely related to a student's ability to complete coursework rather than enrollment in a particular political science class. Several respondents also suggested that academic skills are more important than particular courses. 
One respondent stated that "law school is skills based... [and] a student can get those skills in any major." Another specifically mentioned using advising time "persuading students that lawrelated [course] content is far less important than law school skills development." Future research might consider surveying law school admissions directors and/or law school faculty to determine the specific skills that are useful for success in law school, as well as evaluating whether and how political science departments can provide those skills.

\section{NOTES}

1. We coded faculty $=1$, staff $=0$, and respondents with a JD $=1$; otherwise $=0$. We coded advisors as political scientists if their terminal degree was in political science $=1$; otherwise $=0$. Collegeresults.org provides the Carnegie classifications for all schools, as well as the average SAT score. For ease of interpretation, we collapsed the Carnegie classifications into three: bachelors $=1$, masters $=2$, and doctoral $=3$.

2. Advisors with JDs also were more likely to rate English less positively than non-JDs for success in law school but not admission. They rated philosophy lower across both categories. They did not differ from non-JD advisors regarding a major in history.

3. It is worth noting that this finding does not hold true for several other majors. For example, length of service was not a statistically significant predictor for the ratings of philosophy, history, and English.

4. This effect persists even when the variable for time spent as a pre-law advisor changes from one standard deviation below to one standard deviation above. In that instance, the rating of political science as "Excellent" preparation for admission to law school increases by $10 \%$. It increases by $16 \%$ for preparation for success in law school.
5. Given the lack of statistical significance on the coefficient, we did not calculate the predicted probabilities for performance in law school.

\section{REFERE N C E S}

American Bar Association. 2015. "Preparing for Law School." Available at www. americanbar.org/groups/legal_education/resources/pre_law.html.

Astin, Alexander W. 1984. "Pre-Law Students: A National Profile." Journal of Legal Education 43 (1): 73-85.

Grigsby, Ellen, and Amelia A. R. Murphy. 2012. "The Reach of Our Pedagogy: Political Science Undergraduate Classes and Pre-Law Academic Preparation." In Before the Paper Chase: The Scholarship of Law School Preparation and Admission, eds. Tim Alan Garrison and Frank Guliuzza, 31-40. Durham, NC: Carolina Academic Press.

Haynie, Stacie L. 2014. "The Start (A Coordinated Effort at Pre-Law Advising)." Law and Courts Newsletter 24 (3): 15-17.

Kelley, James L. 1960. "A General Education for Pre-Law Students.” American Bar Association Journal 46 (11): 1184-7.

Knotts, H. Gibbs, and Jennifer S. Schiff. 2015. "Major Competition: Exploring Perceptions of International Studies Programs among Political Science Department Chairs." PS: Political Science \& Politics 48 (1): 142-8.

Law School Admission Council. 2015. "Applicants by Major." Newtown, PA.

Martellaro, Joseph A. 1984. "Business and Economics as Pre-Law Majors." Social and Economic Studies 33 (4): 125-49.

Olson, Elizabeth, and David Segal. 2014. "A Steep Slide in Law School Enrollment Accelerates.” New York Times. December 17.

Rivard, Ry. 2015. "Lowering the Bar." Inside Higher Ed. January 16.

Tamanaha, Brian. 2012. Failing Law Schools. Chicago: University of Chicago Press. 